\title{
ARSENIC AND SELENIUM IN FORMATION WATERS: ENVIRONMENTAL IMPLICATIONS FOR CARBON DIOXIDE STORAGE IN GEOLOGICAL MEDIA
}

\author{
BRIAN HITCHON ${ }^{1} \&$ STEFAN BACHU ${ }^{2}$ \\ ${ }^{1}$ Hitchon Geochemical Services Ltd., Canada \\ ${ }^{2}$ InnotechAlberta Inc., Canada
}

\begin{abstract}
In an attempt to mitigate climate warming, $\mathrm{CO}_{2}$ is being stored in geological media, including deep strata in sedimentary basins where formation waters commonly have high salinity. While there are numerous studies of reactions between injected $\mathrm{CO}_{2}$ and formation waters, little attention has been given to problems which might arise in areas affected by the pressure build-up generated by $\mathrm{CO}_{2}$ injection, which may extend for tens to hundreds of kilometres from the injection site. This paper draws on information from the Alberta Basin (Canada), and considers possible contamination consequences should formation water leak into shallow protected groundwater, with particular reference to As and Se. Arsenic and selenium were determined in 300 formation waters from strata $800 \mathrm{~m}$ or deeper: i.e., at depths and locations potentially suitable for $\mathrm{CO}_{2}$ storage. Although in about $72 \%$ of samples both elements were below detection $\left(0.1 \mathrm{mg} \mathrm{L}^{-1}\right)$, the maximum values for as $\left(86 \mathrm{mg} \mathrm{L}^{-1}\right)$ and $\mathrm{Se}$ (44 $\mathrm{mg} \mathrm{L}^{-1}$ ) are far above those reported in other sedimentary basins. Most samples were from drill stem tests, so contamination by As-bearing chemicals was unlikely. The most likely source for both elements is pyrite present in the aquifer, with chloride being the main removal control. More than 20,000 oil and gas wells in Alberta have lost their integrity, resulting in gas migration and surface casing vent-flow, which, if within the area of pressure build-up, could be conduits for contaminating local groundwater. Dilution up to several thousand times would be required to render these waters safe in the groundwater regime - possible, though with a low probability. These results suggest the need for more attention to the effect of pressure build-up and formation water composition in $\mathrm{CO}_{2}$ storage projects. Keywords: arsenic, selenium, formation water, Alberta Basin, $\mathrm{CO}_{2}$ storage, pressure build-up.
\end{abstract}

\section{INTRODUCTION}

The temperature record on a scale of centuries to millennia indicates an unequivocal warming of the climate, noticeable since the beginning of the industrial revolution, and attributed to an increase in atmospheric concentrations of anthropogenic greenhouse gases (GHG) such as carbon dioxide $\left(\mathrm{CO}_{2}\right)$, methane $\left(\mathrm{CH}_{4}\right)$ and nitrous oxide $\left(\mathrm{N}_{2} \mathrm{O}\right)$ [1]. Land use (agriculture and deforestation) is the most important factor in the increase in $\mathrm{CH}_{4}$ and $\mathrm{N} 2 \mathrm{O}$ concentrations, while the use of fossil fuels for power generation, industrial processes, heating and transportation is the main cause of the increase in $\mathrm{CO}_{2}$ concentration. Arguably, $\mathrm{CO}_{2}$ is the most important of these greenhouse gases and its safe removal from the atmosphere is generally recognized as an important mitigation strategy to alleviate its greenhouse effects on climate, together with improving energy efficiency, energy conservation, and switching from fossil fuels to nuclear energy and renewables [2]. Lately, the main contributors to the growth of anthropogenic $\mathrm{CO}_{2}$ emissions have been population and economic growth, leading to increased energy demand, and increased use of coal in the energy mix, particularly in China and India, which more than cancels the effect of decreasing use of coal for electricity production in the United States as a result of switching from coal to natural gas. Canada, with GHG emissions in the order of $\sim 730 \mathrm{Mt} \mathrm{CO}_{2}$ eq/year, emits approximately $1.6 \%$ of world's greenhouse gases, ranking 10th in the world in terms of its GHG emissions. The province of Alberta is the largest GHG-emitting province in Canada, 
accounting for $\sim 36 \%$ of Canada's emissions, mainly due to the use of fossil fuels for power generation, oil sands production and upgrading, and oil refining. The oil sands industry, which extracts bitumen from oil sands deposits (the third largest heavy oil reserves in the world after Venezuela and Saudi Arabia) currently emits $70 \mathrm{Mt} \mathrm{CO}_{2} /$ year and, under recent provincial legislation, may increase $\mathrm{CO}_{2}$ emissions to $100 \mathrm{Mt} \mathrm{CO}_{2} /$ year.

Carbon dioxide capture from large stationary sources and its storage in geological media (referred to as CCS) was identified early on as one of climate change mitigation options [3] and it is predicted that by $205014 \%$ of electricity production will originate from fossil-fuel power generation associated with CCS [4]. Broecker [5], has reviewed nine possibilities that have been suggested for storing $\mathrm{CO}_{2}$ in geological media. In this paper we are concerned only with two of them - storage in oil and gas reservoirs, and storage in deep aquifers saturated with saline formation water (referred to as deep saline formations), because in both cases formation water ranges from irreducible saturation in some reservoirs to $100 \%$ saturation in deep saline formations. Carbon dioxide injection in geological media is an established technology, as proved by both $\mathrm{CO}_{2}$ enhanced oil recovery $\left(\mathrm{CO}_{2}\right.$-EOR) operations and disposal of acid gas (a mixture of $\mathrm{CO}_{2}$ and $\mathrm{H}_{2} \mathrm{~S}$ resulting from sweetening of sour gas for market distribution). The pore space available for $\mathrm{CO}_{2}$ storage in deep saline formations is huge - immensely greater than in other geological media [3]. Both oil and gas reservoirs and deep saline formations are found in sedimentary basins, which are the locus of fossil fuel resources and, serendipitously, are also the locus of energy production [3], [6]. In the case of the province of Alberta, close to $100 \%$ of its territory is underlain by sedimentary rocks of the Alberta Basin. With carbon taxes increasing by 2022 to $\mathrm{CAD} 50 / \mathrm{t} \mathrm{CO}_{2}$, introduced by both the provincial and federal governments, CCS may become an attractive means of reducing atmospheric emissions of anthropogenic $\mathrm{CO}_{2}$. This is particularly true for the oil sands industry, as demonstrated by Shell's Quest project [7], which was started in 2015 and injects $1 \mathrm{Mt} \mathrm{CO}_{2} /$ year, captured at a hydrogen plant, into the Basal Cambrian sandstone that overlies the crystalline Precambrian basement in the basin.

At its simplest, geological storage of $\mathrm{CO}_{2}$ in sedimentary basins involves the capture at source, transportation to a storage site, and injection into geological media at depths corresponding to the pressure and temperature conditions above its critical point (7.38 $\mathrm{MPa}$ and $31.1^{\circ} \mathrm{C}$, respectively) [3]. Storage is supposed to last operationally for the lifetime of the emitting facility (e.g., up to 50 years for a coal-fired power plant) and indefinitely thereafter (i.e., the injected $\mathrm{CO}_{2}$ will remain permanently in the ground). This means injecting the $\mathrm{CO}_{2}$ as a dense fluid in supercritical state at depths generally more than $800 \mathrm{~m}$ [8]. The injection pressure is greater than the formation pressure and, although the injected $\mathrm{CO}_{2}$ forms a plume around and generally close to the injection site, there is a pressure build-up emanating from the injection well that extends far beyond the locus of the stored $\mathrm{CO}_{2}$. There are various risks associated with the operational (injection) and post-operational phases of $\mathrm{CO}_{2}$ storage in geological media, among them pressure build-up and propagation [9]. The pressure will build up in time increasingly farther away from the injection well during the injection stage, and will dissipate after cessation of injection. It is one of the possible effects of this pressure build-up that concerns us here. Ordinarily, one would expect the induced pressure build-up to be harmless, but in many mature (well-explored and producing) sedimentary basins there are producing, suspended and abandoned wells whose integrity may have been compromised and which may be vulnerable to the pressure build-up induced by long-term $\mathrm{CO}_{2}$ injection. Generally, the density of wells in a sedimentary basin varies, being greatest in producing oil and gas fields, and lowest in background areas with no oil and gas production. For example, the density of wells that penetrate the Viking Formation in the Alberta Basin varies from a mean of 17.1 wells $/ \mathrm{km}^{2}$ in high density areas to a mean of 0.15 wells $/ \mathrm{km}^{2}$ in background 
areas where there are no hydrocarbon reservoirs [10]. But more importantly, in the Viking Formation, many high well-density areas have no hydrocarbon production - the high welldensity resulting from oil and gas reservoirs in deeper strata that may serve as future $\mathrm{CO}_{2}$ storage sites. If the integrity of some wells encountered by the pressure build-up is compromised, they may leak formation water into overlying aquifers, including groundwater aquifers used for human consumption, thus contaminating them. Using data from the Alberta Basin, we will present a scenario in which potable groundwater could be contaminated by As and $\mathrm{Se}$ as a result of potential operations to store $\mathrm{CO}_{2}$ in deep saline formations.

\section{PRESSURE TRANSMISSION AND BUILD-UP IN CO 2 STORAGE OPERATIONS}

Sedimentary formations are characterized mainly by the fact that they are porous, with porosity reaching up to $35 \%$ for unconsolidated sediments. As a result, the flow of fluids in sedimentary formations is characterized as flow in porous media, as opposed to flow through planar features such as fractures and faults, which is characteristic of crystalline rocks. The flow of fluids in porous media is defined by the equation of mass conservation (known as the continuity equation) and Darcy's law, which is an empirical form of the equation of momentum conservation [11]. In the case of non-isothermal flow, the equation for energy conservation needs to be considered as well. The flow rate, expressed by Darcy's law, depends on rock absolute permeability, fluid viscosity and density, and fluid driving forces, such as pressure and buoyancy. In the case of multi-phase flow (e.g., injected $\mathrm{CO}_{2}$ and formation water), the flow rate of the different fluids depends also on their relative permeability and saturation in the pore space. Combining Darcy's law and the continuity equation leads to the diffusion equation for pressure propagation in porous media [11]. The diffusion equation shows that, in addition to the previously-mentioned rock and fluid properties and driving forces, pressure propagation depends also on rock porosity and the compressibility of the porous medium and contained fluids. While formation water can be usually treated as an incompressible fluid, $\mathrm{CO}_{2}$ is highly compressible. The different dependence of the flow rate and pressure propagation on various properties of the porous medium and contained fluids explains why mass flow (in this case of injected $\mathrm{CO}_{2}$ and of displaced formation water) is significantly slower than pressure propagation through the deep saline formation into which $\mathrm{CO}_{2}$ is injected for storage.

As a result of the different rate between flow and pressure propagation, commercial-scale $\mathrm{CO}_{2}$ storage projects can generate a subsurface $\mathrm{CO}_{2}$ plume of linear dimensions of perhaps $10-15 \mathrm{~km}$ in size over their lifetime, while the pressure build-up induced by $\mathrm{CO}_{2}$ injection may propagate over basin-scale dimensions of up to hundreds of kilometres [12]. For example, numerical simulations of $\mathrm{CO}_{2}$ storage in the Basal Cambrian sandstone, in the Alberta Basin, injected at rates between 1 and $16 \mathrm{Mt} \mathrm{CO}_{2} /$ year over a period of 50 years, show that $\mathrm{CO}_{2}$ plumes at the end of injection will reach less than $20 \mathrm{~km}$ in size, while pressure build-up will propagate over $300 \mathrm{~km}$, particularly in the case of multiple $\mathrm{CO}_{2}$ storage sites [13]. These results are similar to those obtained for the Illinois Basin in the U.S. [14], [15]. Even in the case of much smaller scale operations, involving oil production and water disposal, it has been shown that there are adverse pressure transmission effects (with no mass transfer) in an area of Alberta with carbonate reefs overlying a common deep saline formation [16], [17]. Because pressure is highest at the injection well, decreasing outward, regulatory agencies limit the injection pressure to a fraction (e.g., 90\%) of the rock fracturing pressure, regardless of the fluid being injected, in order to maintain the integrity of the confining seal (an aquitard, usually shales or halite beds).

Notwithstanding the limitations on injection pressure imposed by regulatory agencies, numerous studies of pressure effects of $\mathrm{CO}_{2}$ injection, published in the last decade and 
reviewed in [12], show that the effect of pressure build-up needs to be taken into consideration when designing, permitting and operating $\mathrm{CO}_{2}$ storage projects [15]. One of these effects could be penetration of formation water from the injection formation into the confining aquitards (seals), and leakage of $\mathrm{CO}_{2}$ and/or formation water through defective wells into overlying aquifers, up to and including shallow groundwater aquifers that are protected against contamination. As a result of these studies, the U.S. Environmental Protection Agency has issued regulations for $\mathrm{CO}_{2}$ storage operations, that require identification and characterization of the Area of Review (AOR), defined as the area around a $\mathrm{CO}_{2}$ injection well where formation water could be lifted by pressure build-up into protected groundwater (defined in the U.S. as water with salinity up to $10,000 \mathrm{ppm}$ ) whether a pathway exists or not. Further regulations ensure that mitigation measures are taken if there are natural or man-made pathways, such as faults, fractures and defective wells [18].

Oil and gas wells are constructed with multiple engineered barriers against fluid flow leakage into other aquifers, protected groundwater, and/or atmosphere [19]. Local loss of well integrity may occur when there is debonding of cement from casing or from the rock wall, when the well cement has wormholes or fractures, when the well cement is not properly set in the well annulus, or when the casing fails due to stress [10]. In the case of abandoned wells, local loss of integrity may also occur if cement plugs are absent, improperly set, or fractured. In all these cases, leakage of reservoir or formation fluids, inside or outside well casing, will be stopped by the next barrier (e.g., the next cement plug or the next well section with good quality cement). However, if a continuous leakage pathway is formed, then the well loses its integrity and fails as a whole [19]. In a study of more than 300,000 wells in Alberta, Bachu \& Watson [20], have found that approximately $6.5 \%$ of the oil and gas wells in the province have lost their integrity, leading to surface casing vent flow or gas migration. Similar or even higher percentages of well failures have been recorded in other producing sedimentary basins around the world [21]. Considering the high number of oil and gas wells drilled in mature sedimentary basins, their density, their failure rate, and the propagation of pressure build-up over large distances in the case of commercial-scale $\mathrm{CO}_{2}$ storage operations, the flow of formation fluids into shallow protected groundwater is certainly possible, suggesting the need for caution, even if the probability is low. Therefore, the effects of leaking formation water into shallow groundwater need to be taken into account, particularly when the formation water contains relatively high amounts of dissolved toxic elements, such as arsenic and selenium found in the Alberta Basin.

\section{ARSENIC AND SELENIUM IN FORMATION WATERS}

Both As and Se are toxic trace elements with low acceptable amounts in drinking water. In Alberta the maximum acceptable limits are $0.025 \mathrm{mg} \mathrm{L}^{-1}$ for As and $0.01 \mathrm{mg} \mathrm{L}^{-1}$ for Se. Until now, there has been a paucity of data on these elements in formation waters. For example, Collins [22], reports As ranging up to $10 \mathrm{mg} \mathrm{L}^{-1}$ and Se below detection in the formation waters analyzed by his laboratory, but supplied no examples.

Arsenic and selenium have some similar characteristics in aqueous solution. Both occur as anions or neutral species and both exhibit important changes in oxidation states. Further, both elements are closely related to iron in sedimentary cycling, and under reducing conditions may be incorporated into iron sulphides by three possible mechanisms: (1) adsorption onto pyrite precursors, subsequently converted to pyrite; (2) direct adsorption and incorporation into the pyrite lattice; and (3) reaction between pyrite and dissolved As and Se [23]. At near neutral $\mathrm{pH}$ arsenate species $\left(\mathrm{AsO}_{4}{ }^{3-}\right)$ form complexes with iron oxyhydroxides but $\mathrm{As}(\mathrm{III})$ is not complexed on the oxide surface. For selenium the oxidized form is only 
weakly adsorbed (similar to sulphate) whereas Se(IV) is strongly adsorbed under near-neutral conditions [24].

The Alberta Basin is located in western Canada (Fig. 1) and comprises strata ranging in age from Middle Cambrian to Late Tertiary. Complete analyses are available for 537 formation waters that include determinations (mostly by ICP) for As and Se. Of these, 505 samples are from drill stem tests and 32 from producing and injection wells, with 300 of them from strata deeper than $800 \mathrm{~m}$, which is considered to be the minimum depth for $\mathrm{CO}_{2}$ storage. The 300 come from a full spectrum of stratigraphic units: Cretaceous (96), Jurassic to Permian (38), Carboniferous (56), Upper Devonian (78), Middle Devonian (23), Cambrian and Granite Wash (9). Fig. 1 shows the location of formation waters with As and Se $>10$ $\mathrm{mg} \mathrm{L}^{-1}$ and Table 1 presents statistical information on these analyses that is relevant to this study. The range and statistical distribution for chloride, salinity, and temperature and $\mathrm{pH}$ at in situ conditions, are typical of those for the entire basin.

Both As and Se were below detection $\left(0.1 \mathrm{mg} \mathrm{L}^{-1}\right)$ in nearly $75 \%$ of the analyses. The maximum amounts for As $\left(86 \mathrm{mg} \mathrm{L}^{-1}\right)$ and $\mathrm{Se}\left(44 \mathrm{mg} \mathrm{L}^{-1}\right)$ are far higher than those reported in other sedimentary basins. However, formation waters are so seldom tested for either element that there are few data for comparison. Contamination by As-bearing chemicals is unlikely because the majority of samples are from drill stem tests, and the production samples are from untreated wells, so the samples are representative of the respective formation waters.

Fig. 2 is an Eh-pH diagram for all natural waters to which has been added the area occupied by Alberta Basin formation waters (the red rectangle). Table 2 compares statistical parameters between analyses reporting a value for As and Se (rows in bold) and those in which both elements were below detection. Most formation waters fall on the acidic side of neutral and because there is little difference between the two data sets $\mathrm{pH}$ is probably not an important factor in the process that results in high As and Se in some formation waters. Depending on the redox state of these elements it could be important with respect to iron oxyhydroxides, however. If we use either $\mathrm{H}_{2} \mathrm{~S}$ or the saturation index of siderite as a proxy for redox conditions then neither appears to play a part in moving As and Se into formation water (Table 2). Further, both temperature sets are similar, so this also is probably not an

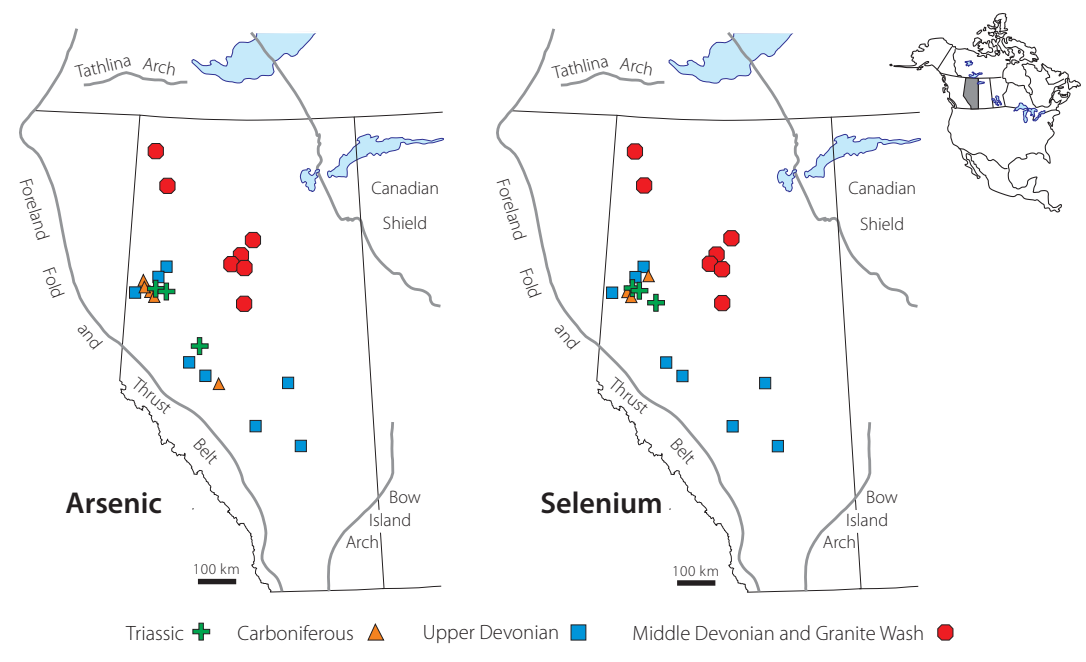

Figure 1: Formation waters with As and $\mathrm{Se}>10 \mathrm{mg} \mathrm{L}^{-1}$ at more than $800 \mathrm{~m}$ depth in the Alberta Basin. 
important factor in the process that results in high As and Se in some formation waters. Although ionic strength shows little difference between the two groups that is not true for chloride, which is consistently higher over most of the statistical range in the formation waters with As and Se. Thus, the easy adsorption of As and Se onto pyrite is reversed with high chloride: both elements are desorbed from pyrite.

Table 1: Selected statistical parameters for 300 formation waters from the Alberta Basin at depths $>800 \mathrm{~m}$ and analysed for both As and Se.

\begin{tabular}{|c|c|c|c|c|c|c|c|c|c|}
\hline \multirow[b]{2}{*}{ Variable } & \multicolumn{9}{|c|}{ Statistical Parameter $[\mathrm{P}=$ percentile; $\mathrm{Q}=$ quartile $]$} \\
\hline & Min & P05 & P10 & Q1 & Q2 & Q3 & $\mathrm{P} 90$ & P95 & $\operatorname{Max}$ \\
\hline $\begin{array}{r}\text { As }\left(\mathrm{mg} \mathrm{L}^{-1}\right)[\mathrm{n}= \\
86]\end{array}$ & 0.20 & 0.70 & 0.87 & 1.5 & 3.0 & 13 & 22 & 36 & 86 \\
\hline $\begin{array}{r}\mathrm{Se}\left(\mathrm{mg} \mathrm{L}^{-1}\right)[\mathrm{n}= \\
84]\end{array}$ & 0.18 & 0.70 & 0.90 & 1.6 & 3.6 & 11 & 22 & 31 & 44 \\
\hline $\begin{array}{r}\text { Salinity } \\
\left(\mathrm{mg} \mathrm{L}^{-1} \times 10^{3}\right)\end{array}$ & 2.5 & 12 & 19 & 33 & 81 & 166 & 206 & 235 & 323 \\
\hline $\mathrm{Cl}\left(\mathrm{mg} \mathrm{L}^{-1} \times 10^{3}\right)$ & 0.6 & 6.0 & 9.1 & 19 & 47 & 100 & 126 & 144 & 200 \\
\hline In situ $\mathrm{pH}$ & 4.3 & 5.1 & 5.4 & 5.8 & 6.2 & 6.6 & 6.9 & 7.1 & 7.6 \\
\hline Temperature $\left({ }^{\circ} \mathrm{C}\right)$ & 24 & 28 & 30 & 35 & 45 & 54 & 84 & 99 & 116 \\
\hline
\end{tabular}

Note. For salinity, $\mathrm{Cl}, \mathrm{pH}$, and temperature, $\mathrm{n}=300$. About $72 \%$ of the determinations for both $\mathrm{As}$ and $\mathrm{Se}$ were below detection $\left(0.1 \mathrm{mg} \mathrm{L}^{-1}\right)$.
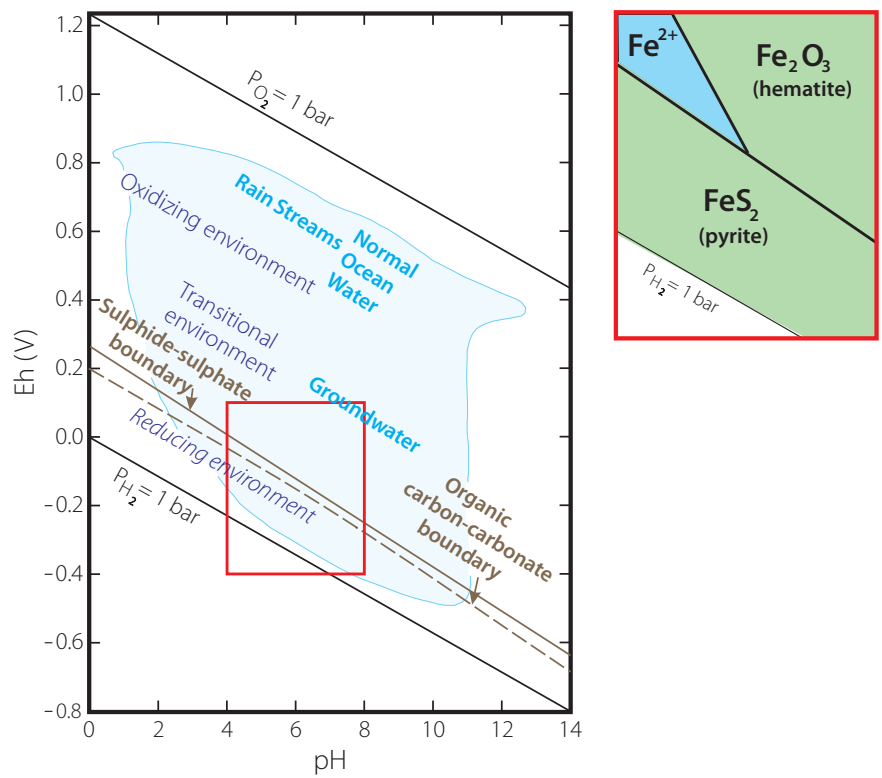

Figure 2: Eh-pH diagram for all natural waters, from [25], modified after [26]. Formation waters in the Alberta Basin fall within the red rectangle. The small diagram shows the Eh-pH field for Fe in the Alberta Basin, occupied by pyrite and iron oxide. 
Table 2: Table 2: Comparison of selected statistical parameters between formation waters at depth $>800 \mathrm{~m}$ and with As and $\mathrm{Se}>0.1 \mathrm{mg} \mathrm{L}^{-1}(\mathrm{n}=111$, rows in bold $)$ and those with both As and Se below detection $\left(<0.1 \mathrm{mg} \mathrm{L}^{-1}, \mathrm{n}=189\right)$.

\begin{tabular}{|r|c|c|c|c|c|c|c|c|c|}
\hline \multirow{2}{*}{ Variable } & \multicolumn{9}{|c|}{ Statistical Parameter $[\mathrm{P}=$ percentile; $\mathrm{Q}=$ quartile] } \\
\cline { 2 - 10 } & Min. & $\mathrm{P} 05$ & $\mathrm{P} 10$ & $\mathrm{Q} 1$ & $\mathrm{Q} 2$ & $\mathrm{Q} 3$ & $\mathrm{P} 90$ & $\mathrm{P} 95$ & Max. \\
\hline In situ $\mathrm{pH}$ & $\mathbf{4 . 4}$ & $\mathbf{5 . 1}$ & $\mathbf{5 . 3}$ & $\mathbf{5 . 7}$ & $\mathbf{6 . 1}$ & $\mathbf{6 . 5}$ & $\mathbf{6 . 8}$ & $\mathbf{6 . 9}$ & $\mathbf{7 . 1}$ \\
\cline { 2 - 10 } & 4.3 & 5.2 & 5.4 & 5.8 & 6.2 & 6.6 & 6.9 & 7.1 & 7.6 \\
\hline $\mathrm{H}_{2} \mathrm{~S}(\mathrm{n}=47)$ & $\mathbf{0 . 0}$ & $\mathbf{0 . 0}$ & $\mathbf{0 . 0}$ & $\mathbf{0 . 0}$ & $\mathbf{0 . 0}$ & $\mathbf{2 . 5}$ & $\mathbf{6 . 0}$ & $\mathbf{9 . 3}$ & $\mathbf{2 5}$ \\
\hline$(\mathrm{n}=69)$ & 0.0 & 0.0 & 0.0 & 0.0 & 0.0 & 0.7 & 9.6 & 17 & 32 \\
\hline Siderite SI $(\mathrm{n}=59)$ & $\mathbf{- 3 . 2}$ & $\mathbf{- 2 . 6}$ & $\mathbf{- 2 . 5}$ & $\mathbf{- 2 . 4}$ & $\mathbf{- 2 . 1}$ & $\mathbf{- 1 . 8}$ & $\mathbf{- 1 . 2}$ & $\mathbf{0 . 0}$ & $\mathbf{0 . 2}$ \\
\hline$(\mathrm{n}=78)$ & -2.8 & -2.5 & -2.4 & -2.2 & -1.9 & -1.5 & -0.8 & -0.7 & -0.2 \\
\hline Temperature $\left({ }^{\circ} \mathrm{C}\right)$ & $\mathbf{2 4}$ & $\mathbf{3 0}$ & $\mathbf{3 2}$ & $\mathbf{3 9}$ & $\mathbf{4 8}$ & $\mathbf{5 9}$ & $\mathbf{8 1}$ & $\mathbf{8 9}$ & $\mathbf{1 1 1}$ \\
\cline { 2 - 10 } & 24 & 27 & 29 & 35 & 43 & 65 & 88 & 105 & 116 \\
\hline Ionic strength & $\mathbf{0 . 0 4}$ & $\mathbf{0 . 3 1}$ & $\mathbf{0 . 4 4}$ & $\mathbf{0 . 9 0}$ & $\mathbf{1 . 9}$ & $\mathbf{3 . 3}$ & $\mathbf{3 . 9}$ & $\mathbf{4 . 4}$ & $\mathbf{5 . 1}$ \\
\cline { 2 - 10 } & 0.08 & 0.26 & 0.52 & 1.3 & 2.6 & 2.8 & 3.9 & 4.4 & 6.2 \\
\hline $\left.\mathrm{Cl}^{(} \mathrm{mg} \mathrm{L}^{-1} \times 10^{3}\right)$ & $\mathbf{1 . 3}$ & $\mathbf{9}$ & $\mathbf{1 4}$ & $\mathbf{3 1}$ & $\mathbf{6 8}$ & $\mathbf{1 0 9}$ & $\mathbf{1 2 6}$ & $\mathbf{1 3 7}$ & $\mathbf{1 8 8}$ \\
\cline { 2 - 9 } & 0.7 & 5 & 8 & 16 & 43 & 88 & 126 & 145 & 200 \\
\hline
\end{tabular}

A scatter plot of As against Se (Fig. 3) shows two features. First, the major portion of the analyses exhibit a close correlation between As and $\mathrm{Se}\left(\mathrm{r}^{2}=0.91\right)$. This supports the suggestion that these two elements come from the same source and in formation waters are controlled by the same physical process. Scatter plots (not shown) of As and Se against in situ temperature and $\mathrm{pH}$ have very low correlations $\left(\mathrm{r}^{2}\right.$ is in the range $\left.0.08-0.25\right)$. Plots for chloride have higher correlations ( 0.47 and 0.32 for As and Se, respectively). This is consistent with the suggestion that the major factor in mobilizing these elements from pyrite into formation water is chloride. Second, three formation waters with As $>40 \mathrm{mg} \mathrm{L}^{-1}$ and 'relatively' low Se comprise a statistical extreme (P95+ in Table 1) - perhaps As in these samples has been mobilized not from pyrite but from arsenopyrite, which is sometimes present as inclusions in pyrite.

Rickard et al. [27], reviewed the geochemistry of sedimentary sulphides and noted that, because $\mathrm{Fe}$ is the most abundant metal in modern sediments, the dominant sulphide is pyrite - which is derived from the products of sulphate-reducing bacteria, in consortium with methane-metabolizing microorganisms. Arsenic and selenium are among the trace elements that may be incorporated into the pyrite structure. The average content of trace elements in modern sedimentary pyrite (e.g., As 339 ppm, Se 226 ppm) differs from those in pyrite from sedimentary rocks (e.g., As 1269 ppm, Se 105 ppm) - the latter includes pyrite from the Precambrian when ocean composition may have been quite different from the modern ocean.

Wolthers et al. [23], reported the highest Se content of pyrite as $0.02 \mathrm{wt} . \%\left(200 \mathrm{mg} \mathrm{kg}^{-1}\right)$ and As in sedimentary pyrite ranges up to almost $0.93 \mathrm{wt} . \%\left(9300 \mathrm{mg} \mathrm{kg}^{-1}\right)$. Levinson [28], lists early (1955) data for the relative percent frequency of these elements in all pyrite - As $(67 \%, n=99)$ and Se $(97 \%, n=115)$. More recently, first-principles calculations show that two-phase mixtures of $\mathrm{FeS}_{2}$ (pyrite or marcasite) and FeAsS (arsenopyrite) are energetically more favourable than the solid solution $\mathrm{Fe}(\mathrm{S}, \mathrm{As})_{2}$ (arsenian pyrite or marcasite) for a wide range of geologically relevant temperatures [29]. Further, pyrite and marcasite can host up to $\sim 6 \mathrm{wt} . \%$ of arsenic in solid solution before unmixing into (pyrite or marcasite) + arsenopyrite. This observation is in agreement with the earlier work of Kolker and Nordstrom [30], who reported randomly distributed areas of early-formed arsenic-poor framboids contained in arsenic-rich zones and a region of arsenic-rich pyrite (6-7 wt.\% As). Interestingly, a study of selenium speciation in framboidal and euhedral pyrite in shales showed that selenium 
speciation is highly dependent on pyrite morphology [31]. So although there is no comparable information for pyrite in the Alberta Basin we should not be surprised to see both elements in formation water.

There is a wealth of data on the sorption and desorption of both As and Se in groundwater but these conditions are not applicable to the environment in which $\mathrm{CO}_{2}$ storage must occur. Besides, groundwaters generally have lower salinity than formation waters. Recent work on the effect of saline formation waters on the removal of arsenic from both pyrite [32] and arsenopyrite [33], demonstrate the importance of both chloride and temperature in this process. However, the experimental conditions of these studies are more relevant to the actual $\mathrm{CO}_{2}$ injection site than to formation waters considered here. That said, they confirm that As can be removed from both pyrite and arsenopyrite and that high chloride and high temperature are important factors - as is the case for lead [34]. There appear to be no comparable studies on the removal of Se from pyrite and arsenopyrite.

\section{ENVIRONMENTAL CONCERNS}

Formation waters with high contents of As or Se are quite safe in the formation. It is when they are brought to the surface that they become an environmental hazard. In the case of oil and gas production, most jurisdictions have a regulatory agency that oversees their safe disposal. This usually involves disposal into a well in a formation other than that producing the oil and gas and at a pressure greater than formation pressure. Two other situations involve pressuring formations: storage of $\mathrm{CO}_{2}$, and hydraulic fracturing of tight formations to produce oil and gas. In each of these three cases, the applied pressure will generate a pressure build-up beyond the injection site, so that we are not so much concerned with the effects at the injection site as with where the pressure build-up travels and if it can result in bringing formation waters with high contents of As and Se to the surface - or even more critically, contaminate groundwater irrevocably.

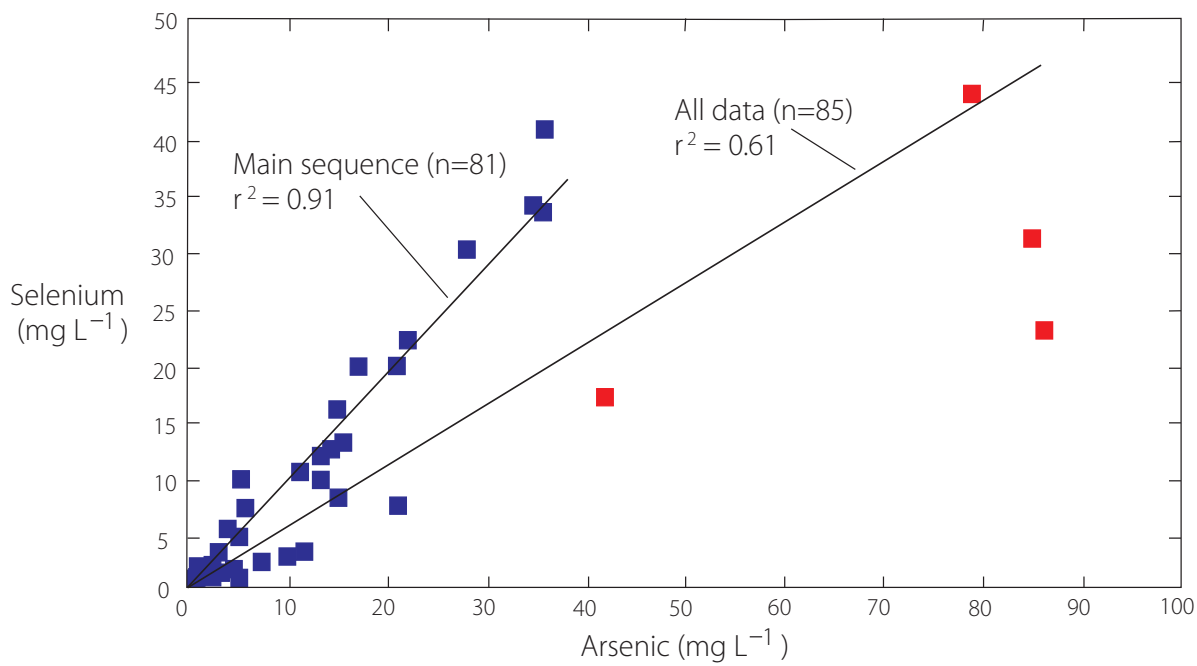

Figure 3: Scatter plot of As and Se in formation waters at depths $>800 \mathrm{~m}$ in the Alberta Basin. The red symbols are formation waters with As levels at P95+ (see Table 1). Some data points represent more than one analysis. 
To obtain a measure of the degree to which these formation waters have the potential to contaminate groundwater we can calculate the dilution required to reduce the As and $\mathrm{Se}$ contents to limits acceptable as potable water in Alberta. For the maximum As $\left(86 \mathrm{mg} \mathrm{L}^{-1}\right)$ they would have to be diluted 3440 times and for the maximum Se $\left(44 \mathrm{mg} \mathrm{L}^{-1}\right)$ they would have to be diluted 4400 times. Although this degree of dilution is certainly possible, contamination by $\mathrm{Cl}$ would likely be observed first because it is more commonly determined than are As and Se. The maximum acceptable chloride in drinking water in Alberta is 250 $\mathrm{mg} \mathrm{L}^{-1}$. Even if the formation waters would be diluted to this amount of chloride, many of the formation waters will still have unacceptable amounts of As and Se. Fig. 4 shows the number of analyses in each of four possible situations of acceptability at a dilution of chloride to $250 \mathrm{mg} \mathrm{L}^{-1}$. Note that Se is the determining element in about $58 \%$ of the analyses. This means that when one is concerned for both As and Se, most effort should be directed at determining Se.

Of the 72 "unacceptable" analyses, 19 are in Cretaceous strata, 22 in Jurassic to Carboniferous strata, 19 in the Upper Devonian and 12 in the Middle Devonian and Granite Wash. One feature that is strongly evident is that both the high-As and high-Se values are spatially interspersed with analyses where the respective element is commonly very low or below detection. This may be a reflection of active drilling in the formations in that area during the time the drill stem tests were run (early 1970s), rather than a real anomaly. Contouring these data would reveal a myriad of "bull's-eyes".

In their review of As in groundwater, Smedley and Kinniburgh [35] state that:

"A characteristic feature of high groundwater As areas is the large degree of spatial variability in As concentrations in the groundwaters. This means that it may be difficult, or impossible, to predict reliably the likely concentration of As in a particular well from the results of neighbouring wells and means that there is little alternative but to analyze each well."

Their observation is certainly true of both As and Se in formation waters in the Alberta Basin. Description of the data set of the analyses considered in this paper, together with an Excel file, are found elsewhere [36].

\section{CONCLUSIONS AND RECOMMENDATIONS}

The Alberta Basin contains some formation waters with high contents of As and Se in deep strata that may be suitable for $\mathrm{CO}_{2}$ storage. The source of both As and Se is likely desorption from pyrite as a result of high chloride in the formation water. These formation waters must not be allowed to come in contact with potable groundwater. This might occur as a consequence of the pressure build-up that in generated through injection of $\mathrm{CO}_{2}$.

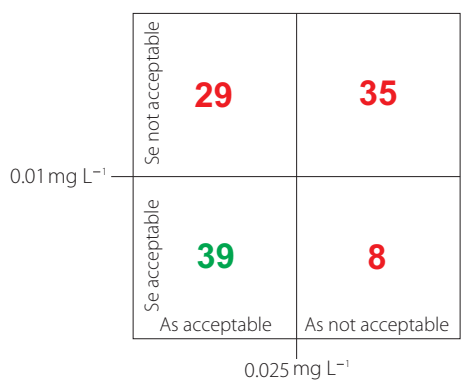

Figure 4: Number of acceptable and unacceptable values for As and Se in formation waters in the Alberta Basin after dilution of the analysis to $250 \mathrm{mg} \mathrm{L}^{-1}$ chloride. 
Although the $\mathrm{CO}_{2}$ plume is confined to a relatively small region around the injection well, the pressure build-up may extend for up to a few hundred kilometres. This means that wells that penetrate the storage formation, and have lost their integrity, are possible conduits for leakage of these formation waters into the zone of potable groundwater. The fewer wells that penetrate the storage unit in the region of increased pressure, the better.

In the absence of comparable information from other sedimentary basins we may use the Alberta Basin as an example of possible groundwater contamination from As and Se that may be associated with other $\mathrm{CO}_{2}$ storage operations. The following precautions should be considered in the planning of a storage project:

- All other things being equal, a storage unit with the fewest well penetrations should be chosen.

- Both As and Se should be determined in all formation waters in the storage unit and immediately overlying strata of the storage complex because of the large degree of spatial variability observed for these elements in both groundwater worldwide and in formation waters in the Alberta Basin.

- All wells that have lost their integrity in the pressure build-up area should be identified and their integrity restored.

- Arsenic and selenium in groundwater should be monitored, especially in areas near wells that have lost their integrity. Because the area of the pressure build-up increases over time, the groundwater monitoring program should be extended over a comparable area.

- The initial groundwater monitoring program identifies the baseline state of all wells. It would be prudent to make periodic checks to ensure that any changes in the content of hazardous elements, including As and Se, are identified as soon as possible. Remediation of a contaminated groundwater aquifer is difficult, if not impossible. The only recourse for the well owner would be removal of the contaminants at the well-head.

In summary, for safe, long-term storage of $\mathrm{CO}_{2}$ it is necessary to demonstrate that the storage complex can accommodate large volumes of $\mathrm{CO}_{2}$ for times that extend beyond the lifetime of the emitting facilities. This means taking into account the areal extent of the pressure build-up at the time it dissipates after injection ceases.

Although this paper deals with $\mathrm{CO}_{2}$ storage - and thus we have been concerned only with formation waters found at depths $>800 \mathrm{~m}$ - it should be quite clear that concern for groundwater contamination should extend to any formation that is subject to an applied pressure because of the generated pressure build-up. The main Alberta Basin formation water data set contains complete analyses of 652 formation waters, including 153 analyses with values for As and 148 analyses with values for Se [34]. The entire data set may therefore be of interest for evaluating possible pressure build-up effects for disposal of waters from both oil and gas fields and hydraulic fracturing.

\section{REFERENCES}

[1] Intergovernmental Panel on Climate Change, Summary for Policy Makers. In: Stocker, T.F. et al. (eds.), Climate Change 2013: The Physical Science Basis. Contribution of Working Group I to the Final Assessment Report of the Intergovernmental Panel on Climate Change. Cambridge University Press: Cambridge, U.K. and New York, 2013.

[2] Intergovernmental Panel on Climate Change, Summary for Policy Makers. In: Edenhofer, O. et al. (eds.), Mitigation of Climate Change. Contribution of Working 
Group III to the Final Assessment Report of the Intergovernmental Panel on Climate Change. Cambridge University Press: Cambridge, U.K. and New York, 2014.

[3] Intergovernmental Panel on Climate Change, Special Report on Carbon Dioxide Capture and Storage, Metz, B., Davidson, O., Coninck, H. de, Loos, M. \& Meyer, L., eds., Cambridge University Press: Cambridge, U.K., 2005.

[4] International Energy Agency (IEA), Energy Technology Perspectives 2014 Harnessing Electricity's Potential. IEA/OECD, Paris, France, 2014.

[5] Broecker, W.S., $\mathrm{CO}_{2}$ capture and storage: Possibilities and perspectives. Elements, 4, pp. 295-97, 2008.

[6] Hitchon, B., Gunter, W.D., Gentzis, T. \& Bailey, R.T., Sedimentary basins and greenhouse gases: a serendipitous association. Energy Conversion and Management, 40, pp. 825-843, 1999.

[7] Nier, M. de, Maasa, W., Gray, L. \& Wiwchar, T., Maturing CCS technology through demonstration - Quest: learning from CCS implementation in Canada. SPE Paper 177878. Presented at the Abu Dhabi International Petroleum Exhibition and Conference, Abu Dhabi, 9-12 Nov., 2015.

[8] Bachu, S., Screening and ranking of sedimentary basins for sequestration of $\mathrm{CO} 2$ in geological media. Environmental Geology, 44(3), pp. 277-289, 2003. DOI: 10.1007/s00254-003-0762-9.

[9] Bachu, S., CO2 storage in geological media: Role, means, status and barriers to deployment. Progress in Energy and Combustion Science, 34, pp. 254-273, 2008. DOI: 10.1016/j.pecs.2007.10.001.

[10] Gasda, S.E., Bachu, S. \& Celia, M.A., Spatial characterization of the location of potentially leaky wells in mature sedimentary basins. Environmental Geology, 46(6)(7), pp. 707-720, 2004. DOI: 10.1007/s00254-004-1073-5.

[11] Marsily, G. de, Quantitative Hydrogeology. Academic Press: London, 1986.

[12] Birkholzer, T.J., Oldenburg, C.M. \& Zhou, Q., CO2 migration and pressure evolution in deep saline aquifers. International Journal of Greenhouse Gas Control, 40, pp. 203220, 2015. DOI: 10.1016/j.jggc.2015.03.022.

[13] Huang, X., Bandilla, K.W., Celia, M.A. \& Bachu, S., Basin-scale modeling of CO2 storage using models of varying complexity. International Journal of Greenhouse Gas Control, 20, pp. 73-86, 2014. DOI: 10.1016/j.jggc.2013.11.004.

[14] Zhou, Q., Birkholzer, J.T., Mehnert, E., Lin, Y.-K. \& Zhang, K., Modeling basin- and plume-scale processes of $\mathrm{CO} 2$ storage for full-scale deployment. Ground Water, (4894), pp. 494-515, 2010.

[15] Birkholzer, J.T. \& Zhou, Q., Basin-scale hydrogeologic impacts of CO2 storage: capacity and regulatory implications. International Journal of Greenhouse Gas Control, 3(6), pp. 745-756, 2009.

[16] Hnatiuk, J. \& Martinelli, J.W., The relationship of the Westerose D-3 pool to other pools on the common aquifer. Journal of Canadian Petroleum Technology, 16, pp. 713, 1967.

[17] Pooladi-Darvish, M., Bachu, S. \& Hong, H., Pressure build-up and decay in acid gas injection operations in reefs in the Zama field, Canada, and implications for $\mathrm{CO} 2$ storage. Oil \& Gas Science and Technology, 66(1), pp. 67-80, 2011. DOI: 10.2516/ogst2010017.

[18] Environmental Protection Agency (EPA), Federal register, 40CFR Parts 124, 144, 145 , et al., Federal Requirements Under the Underground Injection (UIC) Program for Carbon Dioxide (CO2) Geologic Sequestration (GS) Wells, Final Rule, December 10, 2010. 
[19] King, G.E. \& King, D.E., Environmental risk arising from well-construction failure Differences between barrier and well failure, and estimates of failure frequency across common well types, location and well age. SPE Production \& Operation, 28(4), pp. 323-344, 2013.

[20] Bachu, S. \& Watson, T.L., Possible indicators of leakage along wells. Proceedings of the 8th International Conference on Greenhouse Gas Control Technologies (GHGT8), Elsevier, Trondheim, Norway, Jun. 19-22, 2006.

[21] Davies, R.J. et al., Oil and gas wells and their integrity: Implications for shale and unconventional resource exploitation. Marine and Petroleum Geology, 56, pp. 239-254, 2014.

[22] Collins, A.G., Geochemistry of Oilfield Waters. Elsevier: Amsterdam, Oxford, New York, 1975.

[23] Wolthers, M., van der Linde, P.R. \& van der Weijden, C.H., Selenium and arsenic in sedimentary pyrites. Mineralogical Magazine, 62A, pp. 1660-1661, 1998.

[24] Drever, J.I., The Geochemistry of Natural Waters, third edition. Prentice-Hall, Inc.: Upper Saddle River, NJ, 1997.

[25] Baas Becking, L.G.M., Kaplan, I.R. \& Moore, D., Limits of the natural environment in terms of $\mathrm{pH}$ and oxidation-reduction potential. Journal of Geology, 68, pp. 243284, 1960.

[26] Garrels, R.M. \& Christ, C.L., Solutions, Minerals, and Equilibria, Jones and Bartlett Publishers, Inc.: Boston and London, 1990.

[27] Rickard, D., Mussmann, M. \& Steadman, J.D., Sedimentary sulfides. Elements, 13, pp. 117-122, 2017.

[28] Levinson, A.A., Introduction to Exploration Geochemistry. Applied Publishing Ltd.: Calgary, 1974.

[29] Reich, M. \& Becker, U., First-principles calculations of the thermodynamic mixing properties of arsenic incorporation into pyrite and marcasite. Chemical Geology, 225, pp. 278-290, 2006.

[30] Kolker, A. \& Nordstrom, D.K., Occurrence and micro-distribution of arsenic in pyrite. In Proceedings of the USGS Arsenic Workshop, 2001.

[31] Matamoros-Veloza, A., Peacock, C.L., \& Benning, L.G., Selenium speciation in framboidal and euhedral pyrites in shales. Environmental Science \& Technology, 48 (16), pp. 8972-8979, 2014.

[32] Parthasarathy, H., Arsenic dissolution from sedimentary formations under geologic carbon dioxide storage conditions. PhD thesis, Carnegie Mellon University, 2014.

[33] Parthasarathy, H., Liu, H., Dzombak, D.A. \& Karamalidis, A.K., The effect of Na-Ca$\mathrm{Cl}$ brines on the dissolution of arsenic from arsenopyrite under geologic carbon dioxide storage conditions. Chemical Geology, 428, pp. 1-7, 2016.

[34] Hitchon, B., Formation Water Geochemistry. Geoscience Publishing: Sherwood Park, Alberta (in press).

[35] Smedley, P.L. \& Kinniburgh, D.G., A review of the source, behaviour and distribution of arsenic in natural water. Applied Geochemistry, 17, pp. 517-568, 2002.

[36] Hitchon, B., Arsenic and Selenium in Formation Waters, Alberta Basin, Canada: Relevance to Carbon Dioxide Storage - Description of the data set, Hitchon Geochemical Services Ltd., 2017. 